\title{
Monsiváis Writes the (Bi)centennial
}

\author{
Amber Workman \\ University of California, USA
}

\begin{abstract}
Despite his participation in many of the festivities and events related to the (Bi)centennial, Carlos Monsiváis was one of the most direct critics of the commemorations of the initiation of Mexican Independence and the Mexican Revolution. However, in his literary chronicles to date, many of the author's disagreements do not appear; instead, these writings show two general tendencies: 1) the tendency to postpone the $(\mathrm{Bi})$ centennial to another year or transform the festivities into celebrations of something else; and 2) the tendency to mask the author's own preferences, that is, to not take sides in his chronicles on the commemorations. The article inserts Monsiváis's chronicles into a "tradition" of "commemoratory chronicling" and suggests some possible reasons for their somewhat unusual treatment of Mexico's (bi)centennial celebrations.
\end{abstract}

[Keywords: Carlos Monsiváis, Mexican, Independence, Centennial, Revolution, literature.]

Despite his participation in several of the activities and projects held in commemoration of Mexico's 2010 (Bi)centennial, Carlos Monsiváis was, at the same time, one of the most outspoken critics of the fiestas celebrating the initiation of Mexico's movements for Independence and the beginning of the Mexican Revolution. Interestingly, in his literary crónicas (chronicles)' published in the Mexican daily El Universal, the weekly Proceso and his late anthology Apocalipstick (2009), we see few of the author's principal dissatisfactions with the festejos. Instead, these texts, curiously, show at least two general tendencies: 1) that of postponing the (Bi)centennial celebrations to another year or of transforming them into commemorations of something completely different; 2) that of masking the author's preferences; that is, Monsiváis refuses to take sides in these texts. This article begins by describing some of the formal and thematic characteristics of these chronicles by Monsiváis; it then attempts to insert these texts into a "tradition" of writing "commemoratory chronicles" in Mexico; and, finally, it suggests some possible reasons for the seemingly unusual treatment of the (bi)centenary commemorations on behalf of the author. I begin with some historical and literary context.

\section{Monsiváis approaches the (Bi)centennial}

Since 2006 (the year in which preparations for the [bi]centennial commemorations began), Monsiváis's role in the fiestas has been twofold and somewhat paradoxical. On the one hand, he participated in more official activities such as a television series begun by Felipe Calderón concerning the (Bi)centennial and in public fora sponsored by the federal government. In 2008, even the celebration of his seventieth birthday formed part of the commemorations. On the other hand, Monsiváis is the same writer who has cynically referred to the (Bi)centennial as the "autor de milagros" (since it is not possible for a single date to unite all Mexicans and Latin Americans who are also

Rupkatha Journal on Interdisciplinary Studies in Humanities (ISSN 0975-2935), Vol 2, No 3, 2010

URL of the Issue: http://rupkatha.com/v2n3.php

URL of the article: http://rupkatha.com/V2/n3/MONSIVAIS.pdf

(C) www.rupkatha.com 
celebrating Bicentennials); he has also declared as this year's "sacred" term no more or less than "la chingada". In his conferences and colloquia dedicated to the centenarios, Monsiváis promoted, among other things, a focus on historical revisionism and, like many other intellectuals, underlined the need to find solutions to Mexico's social problems and support for marginal groups rather than erecting monuments and planning festivities. Interestingly, this criticism is not that which appears in his crónicas.

\section{"Hidalgo 6, Iturbide 10"}

One of the more creative of Monsiváis's "centenary" crónicas appeared in El Universal in July, 2007 with the title "Sin estatuas, la inmortalidad resulta un disparate". In a certain sense, this text announces what the cronista would claim in his later article "Hidalgo 6, Iturbide 10", from 2008, in which he suggests that, during the (Bi)centennial, Agustín de Iturbide is receiving more attention than Miguel Hidalgo, even though with Hidalgo Mexico's movements for Independence began 100 years ago, while Iturbide is responsible for achieving Independence eleven years later, in 1821. This crónica is fashioned in the form of an imaginary symposium on the (Bi)centennial in which several "actors" involved in the planning of the festejos and who are in the position to contribute to the historical memory on them (and, therefore, also on the history of Mexico, its present and future) - politicians and political scientists, historians, journalists, teachers, all experts on the $(\mathrm{Bi})$ centennial- unite to engage in a dialogue on the upcoming arrival of the "Juicio Histórico". The chronicle consists of four smaller chronicles, all full of the irony, verbal quips and black humor typical of the cronista.

The first section, or first of the small chronicles, suggests that until now there have been very few critical stances on the (Bi)centennial. In this way, in the first "scene" we witness a dialogue between Tíbulo Godínez (politólogo), who proposes that the judgment on politicians be postponed for several years after the (Bi)centennial so that in this way everyone forgets about their shortcomings and Adulatio Romualdo (periodista entregado a la noble causa del entrecomillado), who supports the idea of "la venta de los Bonos del Ahorro Ideológico", proposing that we should stop criticizing altogether: "Usted se abstiene de pensar y México no se polariza". Then, a confused Enjundioso Gómez (Brillante exponente de los ideales de castidad que dinamizarán la familia mexicana) enters the conversation, who doesn't understand which (Bi)centennial we are celebrating. This character believes that 1810 was the year of Hidalgo's birth instead of the birth of the movements for Mexican Independence. Ignoring the protests of Ramiro Villa Rica (Historiador de Buena cuna aunque ya salió de ella y caminó un buen trecho), Enjundioso keeps believing that "Eso de nacer antes es protagonismo. Por decreto, los héroes deberían nacer el mismo día de sus hazañas para que fueran al mismo tiempo Padres e Hijos de la Patria". Nearly all of these characters, including Ana 
Crónica (encargada oficial de la Crónica del Bicentenario) agree that criticism on the (Bi)centennial should be postponed 200 years.

The second crónica, returns us to the topic of national heroes as it is dedicated to a debate on who deserves to be immortalized with a statue and who does not. Here, Fúlgido Lumen (politólogo de la vieja generación) maintains that governors should also be considered as heroes and unless there are documents to prove otherwise, they are innocent and also deserve a statue. Adámico Hervor (Empresario de la nueva generación y por lo mismo senador) declares that there should be "iEstatuas para todos!" while Efeméride Lustrosa (Reportera de sociales) expresses, once again, the idea of postponing all criticism for 200 years and, thus, for the moment, not erect any statues at all. The criteria for the erection of statues comes from Fúlgido:

Que salvo a la Patria en horas de angustia, que salvó a la Patria en horas de felicidad, que se olvidó de la Patria en horas de asueto, que construyó el México moderno, que restauró el México antiguo, que no hizo ninguna de ambas cosas, que soñó con un México justo, que tuvo pesadillas con un México injusto, que fue leal a su vocación republicana. Que se aprendió de memoria a la Constitución de la República y luego murió de meningitis.

Finally, Adulatio consults a Votive Lamp who informs him that approximately 102 , 604 statues will be needed "con dos o tres reemplazos por accidente mortal" and, with this, all are satisfied.

The third and fourth much shorter sections or "mini-crónicas" promote the need for a project, for setting the deadline for the celebration of the (Bi)centenario and, again, for deciding which heroes to commemorate. The third reinforces the idea that a project is missing and promotes, once again, the displacement of the (bi)centenary celebrations as expressed by Aurora Descollante (politóloga, ex-prí́sta, ex-musa de la sociedad civil): "Volvamos a lo del Bicentenario, hay que tener un proyecto, o por lo menos, un anteproyecto, un croquis, un boceto, una lista de sillones ad hoc, algo", to which she receives the following response:

Todos: ¡De prisa, de prisa! ¡A corretear al tiempo! Aurora Descollante: ¿Ya fijamos el plazo?

Adulatio: ¡Claro! De aquí a unos años nos vemos aquí mismo, pero ya tardecito.

In the fourth crónica, the Votive Lamp returns and we meet Eterna Brega (Historiador e instructor de natación en el Popo) who, at last, proposes a list of heroes to commemorate, all chosen from different historical periods and conflicting ideologies: 
Aquí está mi lista: el virrey O’Donojú, Agustín de Iturbide, Lucas Alamán, López de Santa Anna (nos salvó de tener que gobernar Texas, California, Nuevo México, etcétera), Miramón, Maximiliano (conjunto escultórico), Mejía, Porfirio Díaz (tres conjuntos escultóricos), Francisco I. Madero (una banca en La Alameda), Miguel Alemán (seis conjuntos escultóricos y la reposición de la estatua en Ciudad Universitaria), Vicente Fox (un rancho escultórico y una megabiblioteca de bolsillo).

Though lacking in criticism, heroes or plan that makes sense, the (Bi)centennial continues being a celebration of great importance in the ficticious seminar of Monsiváis. While this crónica touches some of the writer's complaints with respect to the celebrations (the lack of criticism or plan at the time the crónica was written), he does not offer many comments and tends to move away from the $(\mathrm{Bi})$ centennial that we are really celebrating.

\section{Monsiváis vs. Rafael López}

In Mexico, we could say that there exists a sort of tradition of penning chronicles on the centenarios in addition, perhaps, to a tradition of "chronicling" the fiestas patrias in general-for instance, Guillermo Prieto, Ignacio Manuel Altamirano, and Luis González Obregón, some of whom were official cronistas of these celebrations. In the early twentieth century, during the centennial commemorations held during the Porfirio Díaz regime in 1910 and those held during the presidency of Álvaro Obregón in 1921, several well-known writers such as Luis Cabrera, Salvador Novo, Carlos González Peña, José de Jesús Núñez y Domínguez, and Rafael López, among others, found in the crónica a means of romanticizing, fictionalizing, or satirizing the centenary festejos, the most splendid and important of the fiestas patrias, and in this way expressed their agreement (or lack of) with the selection of official national heroes (Hidalgo, Juárez, Cuautémoc in 1910; Iturbide in 1921), or in the way in which these commemorations were carried out (with the exclusion of the pueblo, among other things) or the version of history promoted in the festividades.

Rafael López's "commemoratory" crónicas, for example, appearing for the first time in $1921^{\mathrm{ii}}$, are thematically and stylistically similar to those of Monsiváis. In addition to having appeared in the same newspaper, El Universal, they function as ironic and creative critiques of the official hero of the celebrations, making use of fiction, dialogue and humor in order to satirize the centenary celebrations and the manipulation of historical memory. In "El mes de fiestas", for instance, López strolls through the streets of Mexico City and consults with various people about their opinions on the Centenario of 1921. In "Iturbide" "iiii, the cronista laments having to write his weekly crónica in honor of the man who achieved Independence and instead imagines a scenario in which he asks a professional speech writer to do this for him; he tells this person not to "cut Hidalgo any slack" since, in his opinion, this liberator does not deserve commemoration. 
If we compare Monsivais's creative crónicas on the (Bi)centenario to those of López, we see that they do not contrast much in theme or style. However, unlike López, who -employing the use of the more subjective first person narrator, talks about topics such as the exclusion of certain groups from the fiestas, of the national hero and of the way in which official discourse on the Centenario itself gets constructed, shows a clearly contrary position toward certain aspects of it- Monsiváis employs mainly the third person and leaves out certain topics that have been worrisome for him with respect to the celebrations of his day.

Despite the fact that Monsiváis complains that the Revolution has been virtually excluded from the festejos (In his article "Revolución: requiem inaudible", he points out the lesser treatment the Revolution has received in the commemorations) this does not appear in his crónicas, not even those of political character in "Por mi madre, bohemios". Additionally, although Monsiváis favors the inclusion of minority groups or others that have been excluded from the fiestas, this is another topic not represented in his "(bi)centennial" chronicles.

The postponement of the commemorations or the development of criticism on them in 200 years is also curios in Monsiváis's discourse. As we have seen, this appears several times in "Sin estatuas"; and something similar can be seen in his most recent book of chronicles Apocalipstick in which he dedicates the last chapter to the transformation of the commemorations, reconfiguring them into the celebration of the "(Bi)centenario de la Desaparición de la Humanidad Antigua" due to global warming. While the postponement of the criticism on the (Bi)centennial or the displacement of the event itself to the future does coincide with some of the greatest worries of the writer (he laments that no one talks about the festejos in progress, but those that will take place in the future), on postponing, ignoring or changing completely the meaning of the (Bi)centenario, Monsiváis avoids proposing alternatives or solutions: he simply delays, puts off, reconfigures. His crónicas do not touch many of the main conflicts of the (Bi)centennial, not even those he has put forth himself in his other media (ie. television) and writings of non "chronistic" character.

\section{Conclusions}

In my opinion, a series of factors could have influenced this peculiar treatment of the (Bi)centenario in the crónicas of Monsiváis. Monsiváis, on displacing or transforming the celebrations, also postpones his own critical viewpoint on them. Could this displacement be a way to wait until 2010 when the fiestas have ended, to make a better formulated and balanced criticism of them and their treatment of Mexican history? Could the transformation of the festejos into something completely different (the disappearance of humanity) be a way to allude to the fact that the festejos could have repercussions in Mexico City as the central theme of Apocalipstick, but, again, avoid commenting on them in detail? 
Could this be due to the fact that Monsiváis also participated in the festejos, as one of my colleagues aptly points out?

This short article which offers a reading of an obligatorily and, sadly, incomplete sample of Monsiváis's crónicas does not seek to offer solutions to what I consider intriguing in these texts, but to give an idea of the way in which the writer approached the $(\mathrm{Bi})$ centennial through a literary form very much his own. With his rich legacy, a book on the festejos that he left unpublished, and multiple crónicas on the topic that soon will surely appear collected in books or anthologies, Carlos Monsiváis will likely continue to provide us with additional, creative and innovative ways, to consider this year's commemorations.

\section{Notes}

\footnotetext{
' I am adopting a definition of crónica that considers it to be an often highly fictionalized form that sometimes borders on the short story. Additionally, this text appeared in Monsiváis's regular column dedicated to crónicas in El Universal.

ii These were first published in El Universal, in López's "Hebdomadarias" column; later they appeared in his book Prosas transeúntes (1925). I am citing the republished version.

iii In El Universal a more extensive version of this chronicle appears with the title "Gato por liebre".

\section{Bibliography}

López, Rafael. Prosas transeúntes. Mexico: Instituto Nacional de Bellas Artes: 1966.

Martínez Assad, Carlos. "Hidalgo: a cada quien su mito." La Jornada 29 Sept. 200728 Dec. 2007

<http://www.jornada.unam.mx/2007/09/29/index.php?section=sociedad\&article=036n1soc>.

Monsiváis, Carlos. Apocalipstick. Mexico: Debate, 2009.

---. "Hidalgo 6, Iturbide 10." El Universal 30 Nov. 2008. 27 Dec. 2008

$<$ http://www.eluniversal.com.mx/columnas/75428.html>.

---. "Propuestas (desatendibles) sobre un Bicentenario y un Centenario." Proceso 01 Oct. 2007.

---. “¿Qué habría sucedido si...?" Online posting. 21 Apr. 2008.

$<$ http://www.dimensionantropologica.inah.gob.mx/foros/index.php>.

---. "Revolución: réquiem inaudible." El Universal 22 Nov. 2008. 24 Nov. 2008 <http://www.eluniversal.com.mx/columnas/75283.html>.

---. "Sin estatuas la inmortalidad resulta un disparate." El Universal 01 July 2007. 23 Oct. 2008 $<$ http://www.el-universal.com.mx/editoriales/37978.html>.

---. A ustedes les consta. Antología de la crónica en México. Mexico: Ediciones Era, 2006.

Smith, Anthony. National Identity. Reno, NV: U of Nevada P, 1993.

Tejeda, Armando G. "¿Cómo somos? ¿Qué queremos?, pregunta Carlos Fuentes en España.” El Universal 8 June 2007. 06 Jan. 2010 <http://www.jornada.unam.mx/2007/06/08/index.php?section=cultura\&article=a06n1cul>.

Amber Workman is a PhD candidate in Hispanic Languages and Literatures at the University of California, Santa Barbara. E-mail: amberworkman@umail.ucsb.edu 